Please do not remove this page

RMIT

UNIVERSITY

\title{
Patents for drugs and the right to development in international law
}

Owoeye, Olasupo

https://researchrepository.rmit.edu.au/esploro/outputs/9921862392801341/filesAndLinks?institution=61RMIT_INST\&index=null

Owoeye, O. (2015). Patents for drugs and the right to development in international law. Law and Development Review, 8(1), 69-97. https://doi.org/10.1515/ldr-2014-0029

Document Version: Published Version

Published Version: https://doi.org/10.1515/ldr-2014-0029

Repository homepage: https://researchrepository.rmit.edu.au (C) 2015 by De Gruyter.

Downloaded On 2023/04/27 01:18:15 +1000 
Thank you for downloading this document from the RMIT Research Repository.

The RMIT Research Repository is an open access database showcasing the research outputs of RMIT University researchers.

RMIT Research Repository: http://researchbank.rmit.edu.au/

\begin{abstract}
Citation:
Owoeye, O 2015, 'Patents for drugs and the right to development in international law', Law and Development Review, vol. 8, no. 1, pp. 69-97.
\end{abstract}

See this record in the RMIT Research Repository at:

https://researchbank.rmit.edu.au/view/rmit:29799

Version: Published Version

Copyright Statement:

(C) 2015 by De Gruyter.

Link to Published Version:

http://dx.doi.org/10.1515/ldr-2014-0029 


\title{
Olasupo Ayodeji Owoeye* Patents for Drugs and the Right to Development in International Law
}

\begin{abstract}
This article explores the connection of health to human and socioeconomic development and the protection of pharmaceutical patents. It examines the concept of development and the right to development in international law in the context of access to medicines and patents protection. The provisions of the General Agreement on Tariffs and Trade (GATT) and the Agreement on Trade Related aspects of Intellectual Property Rights (TRIPS Agreement) that are significant to the pursuit of development are discussed. The article argues that there is a cognisable right to development in international law that is well recognised in international trade law and the pursuit of development should be duly taken into account in the negotiation and implementation of trade and IP agreements. The article highlights the potential danger in eroding the flexibilities in the TRIPS Agreement through the negotiation of free trade agreements and emphasises the need for IP and trade agreements to sufficiently accommodate and recognise legitimate measures genuinely taken to enhance national development. It is argued that developing countries should have a national IP implementation plan that can effectively enhance their human development objectives.
\end{abstract}

Keywords: intellectual property, international law, development

\section{Introduction}

In a 2005 report, the World Bank, whilst reiterating the position that intellectual property protection is pivotal to development, noted that neither theory nor available studies present conclusive guidance on the likely effects of having strong intellectual property provisions or not having any at all in trade agreements. ${ }^{1}$ The report thus recommended that countries should adopt an IP strategy suitable to

1 See World Bank, Global Economic Prospects 2005 (World Bank 2005), pp. 109-111.

*Corresponding author: Olasupo Ayodeji Owoeye, Faculty of Law, University of Tasmania, Sandy Bay Hobart Tasmania, Hobart, TAS 7005, Australia; RMIT University, Vietnam, E-mail: olasupo.owoeye@hotmail.co.uk 
their level of development and then meticulously determine if any IP provision ought to be included in their various trade agreements. ${ }^{2}$ The United Nations Working Group on the Right to Development in its (1998-2010) report accentuated the need for states to take cognisance of their human rights obligations in negotiating multilateral and bilateral trade agreements in international forums whilst adopting a coherent and coordinated approach to the right to development. ${ }^{3}$ The Working Group further opined that the protection of intellectual property should not weaken the enjoyment of the highest attainable standard of health or limit access to affordable medicines. ${ }^{4}$

The question that arises is whether the international law of development can play a role in ensuring international intellectual property rights are implemented in a manner conducive to the socio-economic circumstances of the countries enforcing them? In the context of access to patented pharmaceuticals by countries in the developing world, can the right to development in international law be relied upon to justify measures adopted to ensure sound health and optimum human development?

Whilst there was a time when health was considered a consequence and not necessarily a determining factor for development, ${ }^{5}$ modern theories of development do recognise the significance of human capital, of which health is an essential component. ${ }^{6}$ The creation of wealth requires, inter alia, a healthy labour force and to that extent, an international agreement with the cardinal objective of fostering socio-economic development through trade in goods and services should not impose conditions likely to constitute real impediments to ability of states to

\section{Ibid.}

3 The Right to Development Report of the Secretary General (UN Doc A/66/216) August 2011, p. 8, available at: <http://www.ohchr.org/Documents/Issues/Development/A.66.216_en.pdf $>$.

4 Ibid., p. 15.

5 See generally P. A. Yotopoulos and J. B. Nugent, Economics of Development: Empirical Investigations (New York: Harper \& Row, 1976); L. Taylor, Macro Models for Developing Countries (New York: McGraw-Hill, 1979); A. C. Kelly, J. G. Williamson and R. J. Cheetham, Dualistic Economic Development: Theory and History (Chicago: University of Chicago Press, 1972); T. Morgan, Economic Development: Concept and Strategy (New York: Harper \& Row, 1975), p. 167.

6 L. J. Currat, A. A. Hyder, T. C. Nchinda and E. Carey-Bumgarner, 10/90 Report on Health Research 1999 (Global Forum for Health Research, 1999), 30, available at: <http://www.isn.ethz. ch/isn/Digital-Library/Publications/Detail/?ots591=eb06339b-2726-928e-0216-1b3f15392dd8\&lng= en\&id=20437>, accessed 22 October 2013; I. B. Tucker, Economics for Today's World (USA: SouthWestern Cengage Learning, 2011), p. 814; see also T. Schrecker, "Development and Health", in P. Haslam, J. Schafer and P. Beaudet (eds.), Introduction to International Development: Approaches, Actors and Issues (Oxford: Oxford University Press, 2009), p. 345, at p. 360.

7 K. Yelpaala, Quo Vadis WTO? The Threat of TRIPS and the Biodiversity Convention Human Health and Food Security 30 Boston University International Law Journal (2012), p. 55, at p. 85. 
improve health. ${ }^{7}$ The World Health Organization (WHO) Commission on Macroeconomics in its 2001 report notes that lack of good health can significantly reduce the incomes of society, individuals and the prospects for economic growth. ${ }^{8}$

The problem with viewing development solely in the context of economic growth is that it fails to take cognisance of the fact that a majority of a country's citizens could be living in impoverished circumstances without access to essential goods whilst only a negligible proportion of the population captures a significant part of the nation's overall wealth. ${ }^{9}$ The human development approach, based on the postulate that a society cannot experience real development without providing its people with the essential needs of life, is yet to receive the recognition it deserves in intellectual property (IP) globalisation. ${ }^{10}$ IP may place a lopsided emphasis on wealth or utility maximisation whilst placing overall global social welfare and the world's most vulnerable people at a disadvantage. ${ }^{11}$ The relation between IP and development is significant for both the developed and developing nations. Given that IP protection essentially imposes monopoly rights that may have significant implications for social welfare and access to knowledge as well as goods essential for human resource development, there is need to situate the protection of IP within the concept of national development.

In the context of access to medicines, food security, technological innovations and human rights, it has been argued that the relations between IP and global governance do not produce fair distributional outcomes. ${ }^{12}$ Whilst current developments may suggest that many developed countries are not dissatisfied with the level of protection offered by existing IP multilateral treaties, developing and least developed countries continue to deprecate IP protection that tends to limit access to medicines, knowledge and other significant development resources. ${ }^{13}$

The article discusses the concept of development and its relevance to international trade law. It examines the right to development in international law

8 Commission on Macroeconomics and Health, Macroeconomics and Health: Investing in Health for Economic Development (World Health Organization, 2001), p. 21.

9 M. Chon, Intellectual Property and the Development Divide, 27 Cardozo Law Review (2006), 2821, at 2832.

10 Ibid.

11 Ibid., 2834.

12 C. Oguamanam, IP in Global Governance: a Venture in Critical Reflection, 2 WIPO Journal, no. 1 (2011), 196, 199.

13 P. K. Yu, The Global Intellectual Property Order and Its Undetermined Future, 1 WIPO Journal, no. 1 (2009), 1. 
and explores its significance to the implementation of the Agreement on Trade Related Aspects of Intellectual Property Rights (TRIPS Agreement) especially in relation to patents for pharmaceuticals. The article highlights the potential danger in eroding the flexibilities in the TRIPS Agreement through the negotiation of free trade agreements and emphasises the need for IP and trade agreements to sufficiently accommodate and recognise legitimate measures genuinely taken to enhance national development. It is argued that developing countries should have a national IP implementation plan that can effectively enhance their human development objectives.

\subsection{The concept of development}

It is increasingly recognised that the term "development" should not be taken in isolation but must be placed in the appropriate context to be capable of meaningful interpretation. ${ }^{14}$ The traditional definitions of development have treated the concept as either historical progress by referring to the unfolding of human history over time in a manner that is considered progressive or development as modernization which views society as moving from a basically traditional condition to a more advanced modern society. ${ }^{15}$ In the late 1950 s and 1960s, the economic growth theory became dominant. ${ }^{16}$ The economic growth theory finds great support in the traditional conceptualisation of development especially in relation to development as modernisation, irrespective of whether the economic growth is measured as Gross Domestic Product (GDP), Gross National Product (GNP) or Gross National Income (GNI). ${ }^{17}$ The equation of development with growth of the economy was well adumbrated in Walt Rostow's Stages of Economic Growth ${ }^{18}$ and still commands significant support till date.

Development has always been one of the essential criteria for defining countries and peoples. ${ }^{19}$ Whilst the development of countries has traditionally

14 M. Chemillier-Gendreau, "Relations between the Ideology of Development and Development Law”, in F. Synder and P. Slinn (eds.), International Law of Development: Comparative Perspectives (UK: Professional Books, 1987), pp. 57, 59.

15 M. McGillivray, "What is Development", in D. Kingbury et al. (eds.), International Development: Issues and Challenges (UK: Palgrave Macmillan, 2008), p. 21.

16 W. A. Lewis, The Theory of Economic Growth (Homewood, IL: Irwin, 1955).

17 McGillivray above n 15, pp. 26-28.

18 W. Rostow, Stages of Economic Growth: A Non-communist Manifesto (Cambridge: Cambridge University Press, 1960).

19 R. Gordon and J. H. Sylvester, Deconstructing Development, 22 Wisconsin. International Law Journal (2004), 1, 2. 
been defined against the backdrop of their economic growth and the standard of living of their citizens, ${ }^{20}$ over time, the concept has been expanded to cover the social development of people as well as economic development. This is because despite the emphasis on economic growth after the Second World War, many alleged that growth in developing countries did not spread to a substantial part of the population and this led to significant disenchantment with the economic growth theory. ${ }^{21}$ In challenging the economic growth theory, Dudley Seers argues that if poverty, unemployment and inequality are getting worse, it would be anomalous to call the result "development" even if per capita income has increased. ${ }^{22}$

Amartya Sen in his seminal work on the link between development and freedom also emphasised the importance of development by writing in the following terms:

The end means of development require examination and scrutiny for a fuller understanding of the development process; it is simply not adequate to take as our basic objective just the maximization of income or wealth, which is, as Aristotle noted, "merely useful for the sake of something else". For the same reason economic growth cannot sensibly be treated as an end in itself. Development has to be more concerned with enhancing the lives we live and the freedom we enjoy. ${ }^{23}$

The United Nations Development Programme (UNDP) in an attempt to shift development strategies from the seemingly excessive emphasis on economic growth promoted the human development concept. According to the UNDP:

Human development is a process of enlarging people's choices. In principle, these choices can be infinite and change over time. But at all levels of development, the three essential ones are for people to lead a long and healthy life, to acquire knowledge and to have access to resources needed for a decent standard of living. If these essential choices are not available, many other opportunities remain inaccessible. But human development does not end there. ${ }^{24}$

20 A. Allot, “The Law of Development and the Development of Law”, in F. Synder and P. Slinn (eds.), International Law of Development: Comparative Perspectives (UK: Professional Books, 1987), pp. 69, 70.

21 E. W. Nafziger, “From Seers to Sen: The Meaning of Economic Development”, in G. Mavrotas and A. Shorrocks (eds.), Advancing Development: Core Themes in Global Economics (UK: Palgrave Macmillan, 2007), pp. 50, 52.

22 D. Seers, The Meaning of Development, 4 International Development Review (1969), 11.

23 A. Sen, Development as Freedom (Oxford: Oxford University Press, 1999), p. 14; also cited in M. Chon, Intellectual Property and the Development Divide, 27 Cardozo Law Review (2006), 2821.

24 UNDP Human Development Report 1990 (Oxford: Oxford University Press, 1990), p. 10. 
The UNDP introduced the Human Development Index (HDI) as an aggregate indicator of human development. The HDI is an aggregate measure of real income per capital, longevity based on life expectancy at birth and educational attainments. ${ }^{25}$

Peter Drahos defines development as being concerned with "achieving $a$ group of objectives for poor people including better educational and job opportunities, greater gendered equality, better health and nutrition, protection of the environment, natural resources and biodiversity". ${ }^{26}$ Richard Peet and Elaine Hartwick reject the idea of viewing economic growth as a metric of development. They maintain that development differs from economic growth because it is connected with circumstances surrounding production as well as social consequences such as income distribution and human welfare. ${ }^{27}$

Although there remains a significant degree of controversy as to the meaning of development, there is an underlying consensus regarding the need to promote growth and reduce hunger, illiteracy, avoidable diseases and poverty. ${ }^{28}$ Viewing national economic growth as a metric of development may not necessarily present an accurate picture of the standard of living of the populace. A nation may be recording substantial economic growth without ensuring an even circulation of the wealth amongst her populace. Economic growth does not necessarily translate to human development but the continual realisation of human development and its sustainability can be greatly enhanced by economic growth. Human development and economic growth are both essential to the elimination of poverty, prevention of diseases, human empowerment and the realisation of the highest attainable standard of living. However, it would be very difficult indeed to experience true development without having a very healthy and highly productive population. Development for the purposes of this article is therefore to be understood in the context of human development.

\subsection{The legal order for International Economic Law}

The Bretton Woods Agreements were signed in 1944 by 44 countries to reduce national trade barriers and guard against economic repression which was

25 Ibid., 109.

26 P. Drahos and R. Mayne, Global Intellectual Property Rights: Knowledge, Access and Development (UK: Palgrave MacMillan, 2002), p. 3.

27 R. Peet with E. Hartwick, Theories of Development: Contentions, Arguments, Alternatives (New York: The Guilford Press, 2009), p. 1-2.

28 See Nafsiger above n 21, 58. 
recognised as one of the factors that instigated World War II. The Agreements culminated in the emergence of the International Monetary Funds and the World Bank. $^{29}$ In 1947, 23 countries adopted the General Agreement on Tariffs and Trade (GATT) to liberalise international trade. The GATT was originally concerned with trade in goods. But since the commencement in 1984 of the Uruguay Round of trade negotiations, which eventuated in the establishment of the World Trade Organisation (WTO) in 1995, the GATT has covered broader themes such as trade in services, investment and IP rights. Today, the impact of the WTO and the suite of associated international trade agreements on socio-economic development on world's populations continue to be an issue of significant interest. $^{30}$ The Preamble of the General Agreement establishing the WTO provides inter alia that Parties recognize that:

.... their relations in the field of trade and economic endeavour should be conducted with a view to raising standards of living, ensuring full employment and a large and steadily growing volume of real income and effective demand, and expanding the production of and trade in goods and services, while allowing for the optimal use of the world's resources in accordance with the objective of sustainable development...

A cardinal objective of the WTO in liberalising international trade is to promote sustainable development in member countries. Whilst less developed countries may find it more difficult to benefit from the international economic system, the GATT contains some provisions to ease their participation in international trade. For instance, Article XXXVI. 8 of the GATT provides that developed contracting parties should not expect reciprocity in relation to commitments made by them in trade negotiations to reduce or eliminate tariffs and should not create other hindrances to the trade of less developed member countries.

The word "development" in the original GATT 1947 context related mainly to the exploitation of resources towards the achievement of economic growth and not necessarily to advance the cause of under-privileged people or peoples. ${ }^{31}$ Over time, though, the advancement of developing economies was accepted as an inexorable consequence of trade expansion. Today, development is portrayed as the all-embracing objective of international trade with the interest of developing countries now considered as requiring careful consideration in trade

29 Ibid.

30 E. D. Kinney, Realization of the International Human Right to Health in an Economically Integrated North America, 37 Journal of Law, Medicine and Ethics (2009), 807, 808.

31 Tomer Broude, The Rules(s) of Trade and the Rhetos of Development: Reflections on the Functional and Aspirational Legitimacy of the WTO, 45 Columbia Journal of Transnational Law (2006), 221, 223.

32 Word Trade Org. [WTO], Ministerial Declaration of 14 November 2001, WT/MIN(01)/DEC/1. 
negotiations. ${ }^{32}$ The increasing emphasis on development in the WTO has been described as the "developmentification" of the WTO, which is considered as being done in furtherance of the WTO's quest for legitimacy. ${ }^{33}$ This is unsurprising in view of the complaints arising from the asymmetrical rules of the WTO, especially in relation to IP protection, and the problems they cause for countries striving to achieve developmental goals bearing in mind that most WTO members are developing countries. ${ }^{34}$

Developing countries face these problems largely due to their weak bargaining positions, particularly in relation to the negotiation of bilateral free trade agreements under the WTO system. The current emphasis on development in the WTO system is seen as not only moving beyond influencing the aspirations associated with the organisation and its traditional mandate, but as signifying the potential recognition of development as a "right" in global economic policymaking in general and the WTO in particular. ${ }^{35}$ The expectation is that developing countries and the general international community can reasonably demand that the policies agreed upon in the WTO should be implemented to serve the right to development which must be understood to entail an obligation to reduce penury and enhance human capabilities all over the world. ${ }^{36}$ The "developmentification" of the WTO thus suggests that development is becoming a benchmark for assessing the success or otherwise of multilateral trade rules ${ }^{37}$ and perhaps the international economic system. Even though the current WTO Doha Development Round has been described as a monumental failure, ${ }^{38}$ the Doha Round nonetheless highlights importance of the pursuit of development to the global governance of trade.

33 Broude above $\mathrm{n}$ 31, 224.

34 See R. Ricupero, "Rebuilding Confidence in the Multilateral Trading System: Closing the "Legitimacy Gap", in G. P. Sampson (ed.), Role of the World Trade Organization in Global Governance (Tokyo: United Nations University Press, 2001), pp. 37, 49-50; Bryan Mercurio, Reconceptualising the Debate on Intellectual Property Rights and Economic Development, 3 The Law and Development Review no. 1 (2010), 65; P. K. Yu, A Tale of Two Development Agendas, 35 Ohio Northern University Law Review (2009), 465, 540-573.

35 Broude, above n 31, 244.

36 Ibid., 245.

37 Sub-Comm. on Promotion and Protection of Human Rights, Mainstreaming the Right to Development into International Trade Law and Policy at the World Trade Organization, U.N. ESCOR, $56^{\text {th }}$ Sess. Agenda Item 4, UN Doc. E/CN.4/Sub.2/2004/17 (June 9, 2004), 15, available at: $<$ http://daccess-dds-ny.un.org/doc/UNDOC/GEN/G04/145/22/PDF/G0414522.pdf?OpenElement>.

38 See D. Kleimann and J. Guinan, The Doha Round: An Obituary (Global Governance Programme Policy Brief, 2011); J. Baghwati, Doha Round: Failure of talks means world lost gains that a successful treaty would have brought (Economic Times June 12012 ). 


\section{The right to development as a human right}

Whilst the right to development can now be said to be cognisable in international law, its status in terms of legal force remains debatable. The United Nations (UN) adopted the Declaration on the Right to Development in 1986. The Declaration has been hailed by some as a significant breakthrough in the history of human rights whilst others have described it as nothing more than a distracting ideological initiative.. ${ }^{39}$ The preamble to the Declaration recognises development as:

... a comprehensive economic, social, cultural, and political process, which aims at the constant improvement of the well-being of the entire population and of all individuals on the basis of their active, free and meaningful participation in development and in the fair distribution of benefits resulting therefrom'. ${ }^{40}$

Article 1.1 of the Declaration describes the right to development as:

an inalienable human right by virtue of which every human person and all peoples are entitled to participate in, contribute to, and enjoy economic, social, cultural and political development, in which all human rights and fundamental freedoms can be fully realized.

Of particular significance to the access to medicines debate is Article 8.1, which provides:

States should undertake, at the national level, all necessary measures for the realization of the right to development and shall ensure, inter alia, equality of opportunity for all in their access to basic resources, education, health services, food, housing, employment and the fair distribution of income.

The Right to Development Declaration may have the long term effect of removing the existing boundary between economic and non-economic development, but it has so far not been a significant means of legal change. ${ }^{41}$

Despite this, the right to development, like the right to health, has assumed the status of a human right in international law. ${ }^{42}$ The right to development

39 I. D. Bunn, The Right to Development: Implications for International Economic Law, 15 American University Law Review (2000), 1425, 1426.

40 UN Declaration on the Right to Development, GA Res 41/128, $97^{\text {th }}$ plen mtg, UN Doc A/RES/ 41/128 (4 December 1986), available at: 〈http://www.un.org/documents/ga/res/41/a41r128.htm>.

41 Chon above $\mathrm{n} 8,2870$.

42 See O. Owoeye, Patents and the obligation to protect health: Examining the significance of human rights considerations in the protection of pharmaceutical patents, 21 Journal of Law and Medicine (2014), 900-919. 
entails the continual improvement of the living standard of individuals and so has significant implications for public health. Accordingly, it stands to reason that trade rules and IP rights should not be enforced in such a way as to obfuscate the ability of people to enjoy this right.

The UN Intergovernmental Working Group on the Right to Development was created to oversee the implementation of the right to development. The Working Group, ${ }^{43}$ in its recommendations for the period 1998-2010, stressed the importance of undertaking social impacts assessments in the areas of trade and development, and to strengthen human rights standards and principles in pursuing impact assessment of trade and development at both national and international levels. ${ }^{44}$ The possible impacts of trade in IP products on economic and human development must therefore be given significant consideration in the negotiation and implementation of trade agreements. It is pertinent to note that the TRIPS Agreement recognises the right of states to legitimately pursue their public interests and developmental goals ${ }^{45}$ and this is discussed further in the next section.

\subsection{TRIPS and development}

The major challenge with the right to development is that, like other social, economic, and cultural rights, its status seems to be considered as more of a political declaration than a legal right. Whilst every state seeks to pursue interests that promote sustainable development, the right to development in international law is yet to assume a level of legal recognition that would make it a powerful defence for derogating from obligations directly arising from international conventions such as the WTO Agreements. This however does not mean the right to development is of no significance in taking advantage of all available flexibilities in the international IP regime. Whilst development as a human right may not have an overwhelming presence, the pursuit of development is still arguably the most powerful justification for IP flexibilities.

43 The Working Group was created by the Commission on Human Rights resolution 1998/72 and endorsed by Economic and Social Council decision 1998/269, with the mandate to monitor and review the progress made in the enforcement and implementation of the right to development.

44 See The Right to Development Report of the Secretary General (UN Doc A/66/216) August 2011, pp. 15-16, available at: 〈http://www.ohchr.org/Documents/Issues/Development/A.66.216_en.pdf>. 45 TRIPS Agreement Articles 7 and 8. 
Due to the fact that the WTO is mostly concerned with trade, IP in the WTO framework is viewed as more or less a commodity. The WTO regime does not seem to take sufficient cognisance of the fact that IP not only encompasses cultural values, the building blocks of education and technological advancement, but it equally protects goods that are essential to social welfare. ${ }^{46}$ The protection of IP should therefore strike a fair balance between access and proprietary interests. ${ }^{47}$ In this regard, the TRIPS Agreement seems to lack robust provisions for the protection of national interests.

The TRIPS Agreement came into effect in 1995 as an integral part of the Marrakech Agreement establishing the WTO. The TRIPS Agreement has been described as a reflection of the triumph of corporate interest in the US and Europe over the wider interests of the vast majority of vulnerable people in the developing world. ${ }^{48}$ It is argued that the TRIPS Agreement was introduced into the Uruguay Round of trade negotiations through the combined efforts of the US and some other industrialised countries to force other countries to recognise their patents and copyrights. ${ }^{49}$ One controversial aspect of the TRIPS Agreement is the provision in its Article 27(1) that makes it mandatory for patents to be available for new inventions in all fields of technology, including pharmaceuticals. This has led to the belief that TRIPS was designed to ensure higher-priced medicines. ${ }^{50}$ With the difficulty arising from protecting public health in a market dominated by pharmaceutical patents monopoly, it becomes pertinent to consider whether poor countries in pursuit of development may rely on the connection between development and health in taking effective measures to address their public health concerns.

The preamble to the TRIPS Agreement expressly recognises developmental and technological objectives as part of the underlying public policy objectives of national systems of IP. It also acknowledges the need for flexibility in the enforcement of IP laws and regulations especially for least developed countries so that they can develop a sound and sustainable technological base. The objectives and principles of the TRIPS Agreement enunciated in Articles 7 and 8 are particularly relevant to the link between IP and development. Article 7 of the TRIPS Agreement provides that the enforcement of IP rights should be "in $a$

46 G. B. Dinwoodie and R. C. Dreyfuss, Designing a Global Intellectual Property System Responsive to Change: The WTO, WIPO and Beyond, 46 Houston Law Review (2009), 1187, 1194-1195.

47 Ibid.

48 See for instance J. Stiglitz, Making Globalization Work (New York: W.W. Norton \& Company, 2007), p. 105.

49 Ibid.

50 Ibid. 
manner conducive to social and economic welfare and to a balance of rights and obligations". In a similar vein Article 8(1) recognises the need for countries to formulate their IP laws to suit developmental goals in the following terms:

Members may, in formulating or amending their laws and regulations, adopt measures necessary to protect public health and nutrition, and to promote the public interest in sectors of vital importance to their socio-economic and technological development, provided that such measures are consistent with the provisions of this Agreement.

This provision came up for interpretation in Canada - Patent Protection of Pharmaceutical Products. ${ }^{51}$ In that case, the EC alleged lack of protection of inventions by Canada in the area of pharmaceuticals under the relevant provisions of the Canadian Patent Act. The EC alleged that Canada's legislation is inconsistent with the TRIPS Agreement, because it did not provide for the full protection of patented pharmaceuticals for the entire duration of the patent term as envisaged by Articles 27.1, 28 and 33 of the TRIPS Agreement. Canada on the other hand contended that Articles 7 and 8 allow some flexibility for governments to adjust patent right to maintain the desired balance between patent protection and public interest. The EC however argued that articles 7 and 8 merely describe the balancing of goals that already took place in negotiating the final text of TRIPS. The Panel in its decision took the view that whilst certain adjustment may be possible, Article 7 and 8 do not give states the right to take measures that would amount to a renegotiation of the basic balance of the TRIPS Agreement. In EC- Trademarks and Geographical Indications (US), the Panel in interpreting Article 8 noted thus:

These principles reflect the fact that the TRIPS Agreement does not generally provide for the grant of positive rights to exploit or use certain subject matter, but rather provides for the grant of negative rights to prevent certain acts. This fundamental feature of intellectual property protection inherently grants Members freedom to pursue legitimate public policy objectives since many measures to attain those public policy objectives lie outside the scope of intellectual property rights and do not require an exception under the TRIPS Agreement. $^{52}$

Peter $\mathrm{K}$. Yu has noted that whether Articles 7 and 8 would be a blessing to developing countries will depend largely on the extent to which member states can use them effectively as much as possible to their advantage. ${ }^{53}$

51 Canada - Patent Protection of Pharmaceutical Products. WT/DS114, 17 Mar. 2000.

52 EC- Trademarks and Geographical Indications (US), WT/DS174/R, 15 March 2005 at 7210.

53 See P. K. Yu, "The Objectives and Principles of the TRIPS Agreement", in Carlos M. Correa (ed.), Research Handbook on the Protection of Intellectual Property Under WTO Rules (USA: Edward Elgar Publishing 2010), p. 149. 
Whilst Articles 7 and 8 allow some degree of flexibility that may attenuate the social costs developing countries would incur in becoming TRIPS compliant, ${ }^{54}$ the objectives and principles of the TRIPS Agreement entrenched in these provisions are yet to be accorded much weight in the implementation of trade agreements and WTO jurisprudence. ${ }^{55}$ These provisions are nonetheless still very significant to developing countries in their implementation of the provisions of the TRIPS Agreement and they can be used to design national IP laws in a manner supportive of human development for the populations of developing countries.

There has been no significant action at the international level towards the implementation of the provisions of Articles 7 and 8. Nor has TRIPS been shown to have enhanced the transfer of technology in real terms. ${ }^{56}$ The emphasis in Article 8 on development can be said to have incorporated a substantive equality principle into the TRIPS Agreement as supported by documents like the UN Millennium Development Goals. ${ }^{57}$ A problem with the weight to be attached to Articles 7 and 8 however stems largely from the fact that their provisions seem to be more hortatory than mandatory. ${ }^{58}$ Another problem is the proviso contained in Article 8 that stipulates that measures taken to enhance socio-economic and developmental goals must be consistent with the TRIPS Agreement. Thus, any measure taken must be expressly or implicitly allowed by the TRIPS Agreement and any measure that is at variance with the provisions of the Agreement may be considered as running afoul of the Agreement. The implication of this is that the promotion of socio-economic interests of a nation must not jeopardise the protection of the rights guaranteed in TRIPS.

The conflict between TRIPS and development has been described as resulting from the need to strike a balance between social desirability of unrestrained dissemination of available know-how and the need for society to create

54 M. von Hase, "The Application and Interpretation of the Agreement on Trade Related Aspects of Intellectual Property Rights”, in C. M. Correa and Abdulquawi A. Yusuf (eds.), Intellectual Property and International Trade: The TRIPS Agreement (UK: Kluwer Law International, 1998), p. 137.

55 See Brazil-Measures Affecting Patent Protection, WTO Doc WT/DS199/1 (8 June 2000); World Trade Organization (2000), Canada-Term of Patent Protection, Appellate Body Report, WT/ DS170/AB/R, para. 101; EC-Trademarks and Geographical Indications (US), WT/DS174/R, 15 March 2005 at 7210.

56 See D. B. Barbosa, M. Chon and M. von Hase, Slouching Towards Development in International Intellectual Property Law, Michigan State Law Review (2007), 71, 124.

57 M. Chon, above n 9, 2836.

58 Ibid. 
economic incentives for creators of new information. ${ }^{59}$ The conflict seems to have been resolved in favour of rewarding the creators of new information. Gutowski has succinctly put the point in context in the following terms:

Yet whether based on the language of rights or utility, the solution that TRIPS offers resolves the conflict squarely in favor of developed nations. TRIPS teaches that while the right to IP protection may not be "right" than the right to sovereign development, it certainly is more powerful. ${ }^{60}$

Ruth Gana (Okediji) opines that although IPRs might also have the status of human rights, the right to development nonetheless is a more compelling interest that overrides rights in inventions. ${ }^{61}$ She suggests that strong protection of IPRs possessed by foreign corporations might have negative economic effects on developing countries because of the ability of right holders to determine the availability or otherwise of certain goods in a given market. ${ }^{62}$ IP is undeniably significant for industrial progress given the protection it offers inventive activities and whilst it may not be the sole prescription for development, it remains an essential part of a development plan. ${ }^{63}$ But the IP component of any national development plan must make allowance for the peculiarities of the society for which it is fashioned. IP protection must not be rigid or excessive as to become a barrier to access or even a more subtle but real impediment to human development.

In sum, whilst TRIPS does recognise the need for countries to take developmental interests into account in the protection of IPRs, its language, on the face of it, does not really allow countries to adopt measures that are not directly or implicitly sanctioned by it, even if these are unequivocally in the public or national interest. Nonetheless, since a fundamental objective of the IP system is to promote socio-economic and technological advancement, it is arguable that measures that are clearly geared towards that end should be presumed to be in consonance with the provisions of TRIPS. A purposive interpretation should therefore be adopted to give effect to such measures, except where they are completely inconsistent or irreconcilable with the provisions of the TRIPS Agreement. This argument is further reinforced by the clear provision of Doha

59 R. J. Gutowski, The Marriage of Intellectual Property and International Trade in the TRIPS Agreement: Strange Bedfellows or a Match Made in Heaven?, Buffalo Law Review (1999), 713, 746. 60 Ibid., 746-747.

61 R. L. Gana (Okediji), The Myth of Development, The Progress of Rights: Human Rights to Intellectual Property and Development 18 Law \& Policy (1996), 315, 326.

62 Ibid.

63 Gutowski, above n 59, 760. 
Declaration on TRIPS and Public Health by which the WTO Ministers in a much quoted provision unequivocally state as follows:

\begin{abstract}
We agree that the TRIPS Agreement does not and should not prevent members from taking measures to protect public health. Accordingly, while reiterating our commitment to the TRIPS Agreement, we affirm that the Agreement can and should be interpreted and implemented in a manner supportive of WTO members' right to protect public health and, in particular, to promote access to medicines for all.

In this connection, we reaffirm the right of WTO members to use, to the full, the provisions in the TRIPS Agreement, which provide flexibility for this purpose. ${ }^{64}$
\end{abstract}

The Doha Declaration on TRIPS and Public Health has therefore given further fortifications to the principle and objectives entrenched in Articles 7 and 8 of the TRIPS Agreement particularly in relation to patents and public health.

\title{
3 Intellectual property and development
}

Development is progressively becoming one of the cardinal objectives of the international legal regime within which IP functions. ${ }^{65}$ Advocates of intellectual property rights have consistently emphasised its importance to economic growth and development. ${ }^{66}$ Nonetheless, it is hardly contestable that IP will only be able to foster economic development where the national IP system is fully supported by appropriate development policies, effective technical infrastructure, human capital and political stability. ${ }^{67}$ There is no gainsaying the fact that development goals may be legitimately pursued within the framework of GATT and the broader corpus of WTO as the whole essence of trade liberalisation is to ensure states are able to record significant economic growth and development.

Intellectual property laws limit the options for liberalising knowledge goods to enhance domestic capacity building for human development. ${ }^{68}$ This is the "development as freedom" model ${ }^{69}$ which is well recognised in the UN

64 Declaration on the TRIPS Agreement and Public Health, WT/MIN(01)/DEC/2, 20 November 2001, para 4.

65 See Barbosa et al., above n 56, 72.

66 See P. Moser, How Do Patents Laws Influence Innovation? Evidence From Nineteenth-Century World's Fairs, 95 American Economic Review no. 4 (2005), 1214.

67 See R. Olwan, A Pragmatic Approach to Intellectual Property and development: A Case Study of the Jordanian Copyright Law in the Internet Age, 35 Loyola of Los Angeles International \& Comparative Law Review (2013), 209, 211.

68 Ibid., 75.

69 Ibid., 76. 
Millennium Development Goals. ${ }^{70}$ The UN Development Programme (UNDP) and the World Health Organization increasingly rely on the human development index as a development metric. ${ }^{71}$ IP and trade institutions on the other hand, adopt the "development as growth" model. ${ }^{72}$ The latter, propounded by the International Monetary Fund and the World Bank, ${ }^{73}$ considers IP as enhancing economic growth through greater access to international trade, foreign direct investment and technology transfer. ${ }^{74}$ Ruth Okediji has advocated the need for resource allocation, including IPRs allocation, to take the promotion of domestic welfare into account as globalisation does not connote a total loss of sovereignty. ${ }^{75}$ In another article, she further argues that the international system should only pierce the sovereignty veil when states fail in their mandate, either by offering inordinate IP protection or having a patently inadequate system of IP protection. ${ }^{76}$

Intellectual property is seen as having the potential of facilitating development by encouraging foreign direct investment, ${ }^{77}$ which is believed to be capable of increasing knowledge capacity, inventive activity and economic growth in developing countries. ${ }^{78}$ Intellectual property seems to promise economic growth to nations through foreign direct investment. This innovation driven growth may, nonetheless, be more of a mirage. This is especially so in least developed countries as multinational companies are unlikely to enter the poorest countries, however strong their IP regime, because consumers would be too poor to pay for the goods. ${ }^{79}$ Besides, many developing countries hold the view

70 United Nations Millennium Declaration, G.A. Res. 55/2, U.N. Doc. A/RES/55/2 (Sept. 18, 2000), available at: <http://www.un.org/millennium/declaration/ares552e.htm>.

71 See UNDP, Human Development Report 1991; World Health Organization, Guiding Principles for Strategic Resource Allocation, RC/2005/1 (1 June 2005), available at: <http://www.euro.who. int/_data/assets/pdf_file/0004/88006/RC55_erc_2005_1.pdf >.

72 Barbosa et al. above $n$ 56, 77.

73 J. E. Stigliz, Globalisation and its Discontents (New York: W.W. Norton \& Company, 2002).

74 D. J. Gervais, Intellectual Property, Trade \& Development: The State of Play, 74 Fordham Law Review (2005), 505, 516-520.

75 R. Okediji, Copyright and Public Welfare in Global Perspective, 7 Indiana Journal of Global Legal Studies (1999), 125.

76 R. L. Okediji, The Institutions of Intellectual Property: New Trends in an Old Debate, 98 American Society of International Law Proceedings (2004), 219, 221.

77 K. E. Maskus and J. H. Reichman, "The Globalization of Private Knowledge Goods and the Privatization of Global Public Goods”, in K E. Maskus and J H. Reichman (eds.), International Public Goods and Transfer of Technology Under a Globalized Intellectual Property Regime (Cambridge: Cambridge University Press, 2005), pp. 3, 11-15.

78 Gervais, above n 74, 508-509.

79 Commission on Intellectual Property Rights, Integrating Intellectual Property Rights and Development Policy (2002), 40-46, available at: <http://www.eldis.org/go/home\&id=10898 \&type=Document\#.VNallizpUWs $>$. 
that a harmonised system that seeks to establish a stronger IP regime would only benefit some developed countries at the detriment of many developing countries. $^{80}$ For instance, it was revealed in a particular study that the major beneficiary of the TRIPS Agreement is the US with developing nations being the major contributors. ${ }^{81}$ This is because the US is the biggest producer and exporter of IP products in the world and the developing countries are the major importers of such products.

The role of IP in economic growth inevitably varies from country to country. ${ }^{82}$ Whilst IP has played a significant role in the economic advancement of the US over the last three decades, it is also true that until 1982, the US had one of the world's least protective patent laws. It also had weak copyright law until 1978 and its competition law was largely interventionist with a strong doctrine of patent misuse until the 1980s. ${ }^{83}$ Countries like Brazil, China, India, Japan, Korea, and Malaysia were all able to record significant economic growth without strong IP protection. ${ }^{84}$ India developed a very strong generic pharmaceutical industry because of its prohibition on the grant of product patents for pharmaceuticals prior to the country's full implementation of the TRIPS Agreement in $2005 .{ }^{85}$ It is nonetheless arguable that emerging economies like China, Brazil, and Korea may not attain significant levels of economic growth in the future if they did not comply with TRIPS ${ }^{86}$ as they may be unable to convert their indigenous intangibles into commercial knowledge goods without the suitable IP laws and policies. $^{87}$

80 D. Chun, Patent Law Harmonization in the Age of Globalisation: The Necessity and Strategy for a Pragmatic Outcome, 93 Journal of Patent and Trademark Office Society (2011), 127, 129.

81 P. McCalman, Reaping What You Sow: An Empirical Analysis of International Patent Harmonization (Working papers in Economics and Econometrics, June 1999), 30.

82 J. H. Reichman, Intellectual Property in the Twenty-First Century: Will the Developing Countries Lead or Follow? Houston Law Review (2009), 1115, 1116.

83 Ibid., 1117.

84 R. C. Dreyfuss, The Role of India, China, Brazil and Other Emerging Economies in Establishing Access Norms for Intellectual Property and Intellectual Property Law-making (Int'l Law \& Justice Working Paper 2009/5, 2009), 2-4, 11.

85 A. Kapczynski, Harmonization and Its Discontents: A Case Study of TRIPS Implementation in India's Pharmaceutical Sector, 97 California Law Review (2009), 1571.

86 Dreyfuss, above $n 84$.

87 D. Gervais, “TRIPS and Development”, in D. J. Gervais (ed.), Intellectual Property, Trade and Development: Strategies to Optimise Economic Development in a TRIPS Plus Era (Oxford: Oxford University Press, 2007), p. 3; P. Yu, "Intellectual Property, Economic Development, and the China Puzzle”, in D. J. Gervais (ed.), Intellectual Property, Trade and Development: Strategies to Optimise Economic Development in a TRIPS Plus Era (Oxford: Oxford University Press, 2007), pp. 173, 195. 
Developing countries need to devise a national plan that will enable them to catch up with technologically advanced countries and this may require having IP laws that are not unduly protectionist. In the famous words of Williams Kingston, "From the start of the industrial revolution, every country that became economically great began by copying: the Germans copied the British; the Americans copied the British and the Germans, and the Japanese copied everybody." 88 Indeed, as noted by Peter Yu, history is filled with cases of countries that successfully advanced from the developing, copycat phase to the stage where they are fully innovative and developed. ${ }^{89}$ Bryan Mercurio has however argued that countries can no longer use weak IP protection to facilitate industrial development as done by early industrialising countries but they can use all the flexibilities available in international intellectual property law to develop policies that will advance their technological growth and socio-economic development. $^{90}$ China's experience has been described by Peter $\mathrm{K} \mathrm{Yu}$ as a good example of how the development of a well-functioning patent system specially designed to reflect national goals and interests can serve as an important tool in fostering economic development and technological proficiency.

Intellectual property rights are nonetheless just one component of overall economic growth and, as Reichman puts it, for countries at the early stage of development:

A sound agricultural policy or a sound pro-competitive industrial policy with a supportive political and legal infrastructure are more likely to stimulate economic growth than intellectual property laws. ${ }^{91}$

Reichman further notes that the experience in a number of OECD countries is beginning to show that excessively protectionist IP regimes can stifle innovation by making it too expensive and cumbersome to achieve whilst properly designed IP laws protect small and medium size firms from the anti-competitive practices of larger corporations. ${ }^{92}$

88 W. Kingston, “An Agenda for Radical Intellectual Property Reform”, in K. Maskus and J. H. Reichman (eds.), International Public Goods and Transfer of Technology under a Globalised Intellectual Property Regime (Cambridge: Cambridge University Press, 2005), p. 653, at p. 658.

89 See P. K. Yu, Five Oft-Repeated Questions About China's Recent Rise as a Patent Power, Cardozo Law Review De Novo (2013),78, 98.

90 Bryan Mercurio, Reconceptualising the Debate on Intellectual Property Rights and Economic Development, 3 Law and Development Review, no. 1 (2010), 65, 79.

91 J. H. Reichman, Intellectual Property in the Twenty-First Century: Will the Developing Countries Lead or Follow?, Houston Law Review (2009), 1115, 1117.

92 Ibid., 1121. 


\subsection{Patent harmonisation and development}

The agitation for a harmonised patent system is in response to the overwhelming challenges posed by globalisation and internationalisation. ${ }^{93}$ The limited capability of patent offices and the growing number of patent backlogs are some of the reasons for seeking a harmonised framework. ${ }^{94}$ For instance, it is estimated that two million patent applications pending before the United States Patents and Trademark Office, European Patent Office and Japan Patent Office as of 2008 could be four million in ten years. ${ }^{95}$ Additionally, the patenting of emerging advanced technologies requires highly specialised knowledge that makes it expedient for patent offices to cooperate internationally in issuing timely patentability criteria. ${ }^{96}$ The quest for harmonisation therefore has arisen as a result of the need to devise a practical and effective solution to the problem of increasing number of patent applications and haphazard validity criteria in a globalised world. ${ }^{97}$

The "one size fits all" approach to IP may, on a global scale, aggravate the difficult and significant inequalities of access and information that are the current features of development in regional and national terms. ${ }^{98}$ It is doubtful whether the current exceptions and limitations to patent rights suffice to give force to domestic welfare values as global IP policy makers continue to view patents in property rights terms. ${ }^{99}$ The substantive legal harmonisation of patent law may be viewed with circumspection in countries with no competitive framework for patent protection. ${ }^{100}$ This is because implementing a harmonised system would involve making alterations to existing legislation, strengthening IP administration, and providing effective administrative framework for enforcement, all of which would certainly entail a huge financial cost particularly in developing countries. ${ }^{101}$

93 Chun above, n 80, pp. 142-147.

94 E. R. Kazenske, Patent Offices: Strategies For Work Sharing (Fordham IP Conference 2009), available at: <http://fordhamipconference.com/wp-content/uploads/2010/08/Kaz_Kazenske_ Patent_Offices_Strategy_for_Work_Sharing.pdf $>$.

95 Five IP Offices, Objectives (2008), available at: <http://www.fiveipoffices.org/obj.html>.

96 Shinjiro Ono, Substantive Patent Harmonization and Japan's Stance, Japan Patent Office (JPO), available at: <http://www.ppt2txt.com/r/d17a6398/>.

97 Chun, above n 74, 142-147.

98 K. Aoki, Toward a Cultural Geography of Authorship, 48 Stanford Law Review (1996), 1293, pp. 1344-1345.

99 Ibid., 1345-1347.

100 Chun above, n 74, 142-147.

101 Ibid. 
The harmonised system established by the TRIPS Agreement may also impede state's freedom to use their discretion in fashioning a system that suits their peculiar needs. Given that most developing countries are far from being in the frontline of innovative activities, they would ordinarily prefer a patent system that would be flexible enough as not to constitute a potential or real threat to national development. The harmonised system enshrined in TRIPS has, conversely, restricted to a large extent the ability of developing countries to use patents as a tool for fashioning national economic and industrial policies that would bring about sustainable development. ${ }^{102}$ Jerome Reichman and Rochelle Dreyfuss put the position succinctly when they opine that it would be ill advised to adopt deep substantive harmonisation as that would further impede technological advancement in developing countries. ${ }^{103}$

Although TRIPS prohibits "free riding" that would impede the recovery of costs invested in research and development, it is capable in its own right of impeding development by reducing the spread of technology, stifling innovation and hampering the ability of developing countries to compete in markets currently being controlled by the industrial world. ${ }^{104}$ It is therefore expedient to interpret TRIPS in a way that recognises the potential hindrances that rigid IP standards may pose to human development. ${ }^{105}$ Dongwook Chun has argued that since substantive legal harmonisation of the patent system is difficult to achieve, substantive administrative measures might be a more realistic alternative as they do not require changing existing laws or concluding international conventions. ${ }^{106}$ The substantive administrative measures could avoid heavy financial costs or the need to pass through the rigorous process of obtaining parliamentary approval. ${ }^{107}$ Chun argues that the substantive administrative harmonisation would be implemented through the cooperation of interested patent offices and it would focus on the patent prosecution process rather than the enforcement or

102 N. K. Mohanty, The Advantage/Disadvantage of the Harmonization of the Patent System (Mar. 2008), 60, available at: <http://www.jpo.go.jp/torikumi_e/kokusai_e/pdf/ipcoop_asiapacific_e/india02.pdf>; Getachew Mengistie, The Impact of the International Patent System on Developing Countries (World Intellectual Property Organization, 2003), 33, available at: <http:// www.wipo.int/edocs/mdocs/govbody/en/a_39/a_39_13_add_1.pdf>.

103 J. Reichman and R. C. Dreyfuss, Harmonisation Without Consensus: Critical Reflections on Drafting a Substantive Patent Law Treaty, 57 Duke Law Journal (2007), 85, 91.

104 J. H. Barton, J. L. Goldstein, T. E. Josling, R. H. Steinberg, The Evolution of the Trade Regime: Politics, Law and Economics of the GATT and WTO (Princeton: Princeton University Press, 2006), p. 142.

105 Barbosa et al., above n 39, 91.

106 Chun, above n 74, 147-148.

107 Ibid. 
infringement, which would require some legal foundation. ${ }^{108}$ The basic goal of the substantive administrative measure is work sharing ${ }^{109}$ which, it is believed, will give patent offices a better understanding of each other's work method. ${ }^{110}$

Whilst administrative harmonisation will undoubtedly make it easier for countries to offer IP protection that is not adverse to their national interest, the drafters of the TRIPS Agreement desired more than mere administrative harmonisation. The need for a global framework for IP protection necessitated not just administrative but substantive harmonisation. The substantive harmonisation process has reached a level where it would be futile to recommend its abrogation. The preferred option is to work with a substantive harmonisation framework that makes allowance for countries to differ on points of detail where socio-economic and technological development interests so require. If all states act in good faith in pursuing substantive harmonisation without fostering the interest of well-developed economies at the expense of those struggling to develop, it could hold long-term benefits for all nations irrespective of their current level of development.

\subsection{The WTO and WIPO development agendas}

The concerns of the developing world over the shortcomings of the TRIPS Agreement and international framework for patent protection led to a concerted push for the establishment of a developmental agenda at the beginning of the new millennium. ${ }^{111}$ This has also brought about a more IP conscious public. ${ }^{112}$ The WTO Doha Round was launched following the September 11 attacks to nurture public confidence in the WTO and give greater weight to the interests of less developed nations. ${ }^{113}$ Whilst the Doha Round focussed largely on access to medicines in developing countries, it also considered issues such as the connection between TRIPS and the Biodiversity Convention and the protection of folklore and traditional knowledge. ${ }^{114}$

\section{Ibid. \\ 109 Ibid. \\ 110 Ibid.}

111 P. K. Yu, The Global Intellectual Property Order and Its Undetermined Future, 1 WIPO Journal, no. 1 (2009), 1, 11.

112 See P. K. Yu, A Tale of Two Development Agendas, 35 Ohio Northern University Law Review (2009), 465, 540-573.

113 L. Amoore et al., Series Preface to Amrita Narlikar, International Trade and Developing Countries: Bargaining Coalitions in the GATT \& WTO (Routledge, 2003), xiii; see also. 1.2.2. above. 114 Word Trade Org. [WTO], Ministerial Declaration of 14 November 2001, WT/MIN(01)/DEC/1, 41 I.L.M. 746 (2002); Yu, above n 91, 515. 
In parallel, Argentina and Brazil introduced a proposal to establish a WIPO Development Agenda to the WIPO General Assembly in October 2004. The WIPO Development Agenda was formally adopted by the WIPO General Assembly in October 2007. ${ }^{115}$ Paragraph 9 of the Development Agenda provides that WIPO should promote the use of IP and technical cooperation in a manner supportive of public interest flexibilities and technological development. ${ }^{116}$

It further emphasises the need for IP agreements and minimum standards to be fashioned in a way responsive to the different levels of development and social needs and industrial challenges of member countries ${ }^{117}$ Sisule Musungu and Graham Dutfield have argued that WIPO should pursue broad development measures that would ensure developing countries are not deprived of the benefits of the modern scientific and technological advancements in health, communication technology, food and nutrition amongst others. ${ }^{118}$

According to Neil Netanel, the WIPO Development Agenda favours the position that strong IP protection does not necessarily promote creativity, technology transfer or development. ${ }^{119}$ He notes that the Agenda has firmly placed the advantages of national flexibilities in the implementation of IP treaty provisions, access to knowledge and UN development objectives within WIPO's mandate. ${ }^{120}$ Whilst it is easy to focus on the concerns emanating from the TRIPS Agreement and efforts to address them in the Doha Round, ${ }^{121}$ it is also important not to ignore current developments in WIPO that may equally play a profound role in resolving some of the major concerns in the global IP regime.

The concept of development has not been given a particular definition in the WTO jurisprudence. The WTO Appellate Body tacitly avoided a functional definition of development in the GSP case but it noted that different countries may have different development needs. ${ }^{122}$ India had alleged in the GSP case that the

115 WIPO Press Release, Member States Adopt a Development Agenda for WIPO (Oct. 1, 2007), available at: <http://www.wipo.int/pressroom/en/articles/2007/article_0071.html .

116 WIPO, Proposal to Establish a Development Agenda for WIPO: An Elaboration of Issues Raised in Document WO/GA/31/11, IIM/1/4 (April 6, 2005).

117 Ibid.

118 S. F. Musungu and G. Dutfield, Multilateral Agreements and a TRIPS-plus World: The World Intellectual Property Organisation (WIPO) (Quaker United Nations Office, TRIPS Issues Paper No. 3, 2003), 18, available at: <http://www.quno.org/geneva/pdf/economic/Issues/MultilateralAgreements-in-TRIPS-plus-English.pdf $>$.

119 N. W. Netanel (ed.), The WIPO Development Agenda and Its Development Policy Context (Oxford: Oxford University Press, 2009), pp. 1, 2.

120 Ibid.

$121 \mathrm{Yu}$, above n 91, 521.

122 Appellate Body Report, European Communities-Conditions for the Granting of Tariff Preferences to Developing Countries, WT/DS246/AB/R (Apr. 7, 2004), pp. 157-174. 
European Communities (EC) scheme of generalised tariff preferences (GSP scheme) would affect India's export of pharmaceuticals to the EC and was therefore inconsistent with the most-favoured nation principle and the Decision on Differential and More Favourable Treatment, Reciprocity, and Fuller Participation of Developing Countries (the "Enabling Clause"). ${ }^{123}$ The Appellate Body, whilst acknowledging that the development needs of countries are bound to differ, found that the EC was bound to accord the same treatment to similarly situated GSP beneficiaries and that the EC had failed to justify the challenged measure under the Enabling Clause. The Panel similarly noted in Brazil-Export Financing Programme for Aircraft that the question of what the development needs of a nation are is one within the exclusive preserve of the developing country in question. ${ }^{124}$ Canada had argued in that case that the use of export subsidies by Brazil under the WTO Agreement on Subsidies and Countervailing Measures was inconsistent with Brazil's development needs. The Panel noted that the question of development needs was of a peculiarly economic and political nature and one that the Panel was not competent to review. The Panel held the view that Canada had failed to present sufficient evidence to raise a presumption that Brazil's use of export subsidies was inconsistent with her development needs. In the words of the Panel:

... an examination as to whether export subsidies are inconsistent with a developing country Member's development needs is an inquiry of a peculiarly economic and political nature, and notably ill-suited to review by a panel whose function is fundamentally legal. 239 Further, the SCM Agreement provides panels with no guidance with respect to the criteria to be applied in performing this examination. We consider that it is the developing country Member itself which is best positioned to identify its development needs and to assess whether its export subsidies are consistent with those needs. Thus, in applying this provision we consider that panels should give substantial deference to the views of the developing country Member in question.

The sense of restraint exercised by the WTO judicial body in introducing development concerns into the WTO jurisprudence is understandable in view of the fact that doing so might disrupt the heritage of trade rules. It will also be very difficult to decipher the legal confines of the concept of development from the myriad largely directory legal texts making reference to it. ${ }^{125}$ The WTO trade regime is built on the foundational Most Favoured Nations (MFN) principle which is a firmly established norm. However, the pursuit of development requires some relativity

123 GATT/WTO Decision on Differential and More Favourable Treatment, Reciprocity, and Fuller Participation of Developing Countries.

124 Panel Report, Brazil-Export Financing Programme for Aircraft, 7.89, WT/DS46/R (Apr. 14, 1999). 125 Broude, above n 31, 254. 
and divisibility which would require the WTO functional principle of MFN to give way to new aspirations. ${ }^{126}$ The MFN reciprocity principle may however be largely unsuitable for an institutional system that seeks to promote development goals in poor countries rather than obliterating trade barriers. ${ }^{127}$

In sum, there seems to be a general trend within WIPO and the WTO towards ensuring that the IP system takes development concerns into account. This will require a degree of relativity which, prima facie, may appear incompatible with the WTO MFN principle, but arguably is still capable of being accommodated within the WTO system through the use of free trade agreements. WIPO seems to have been more responsive so far to the development concerns of poor countries than the WTO and there is need for the WTO to take the concept of development beyond a mere inchoate recognition to a more cognisable obligation in its institutional framework. Whilst the Doha Development Round has so far been unable to achieve it lofty goals, there is still a strong need for an effectual recognition of development in the global IP system. To reiterate the observation of the IPR Commission:

\footnotetext{
We believe that a prerequisite for sustainable development in any country is the development of an indigenous scientific and technological capacity. This is necessary to allow countries to develop their own process of technological innovation, and to enable them to absorb effectively technologies developed abroad. It is obvious that the development of such capacity is dependent on a large number of elements. It requires an effective education system, particularly at the tertiary level, and a network of supporting institutions and legal structures. It also requires the availability of financial resources, both public and private, to pursue technological development. There are many other factors that contribute to what are often known as "national systems of innovation"128
}

The implementation and enforcement of IP in developing countries should therefore be geared towards the advancement of their technological capacity. This will inexorably require a national IP plan that suits local circumstances.

\section{Pharmaceutical patents, development and the TRIPS flexibilities}

It has been argued that the TRIPS Agreement holds more benefits for developed countries and that IP protection has not been shown to result in any significant

126 Ibid., 258.

127 Ibid., 259.

128 Commission on Intellectual Property Rights, Integrating Intellectual Property Rights and Development Policy: Report of the Commission on Intellectual Property Rights (2002), 20. 
development for developing countries. ${ }^{129}$ There exists a real nexus between health and development and the access to medicines problem consequently has significant implications for human capacity building and development. Human rights activists in particular have been pursuing human rights advocacy to enhance access to medicines especially with respect to the HIV/AIDS epidemic. ${ }^{130}$ It has been highlighted that in Latin America, advocates have been able to successfully rely on human rights provisions in national constitutions to compel governments to provide HIV treatment for people living with the disease. ${ }^{131}$ The efforts of activists also resulted in the establishment of a scheme to procure and make available drugs for those in need through the public health system in Brazil. ${ }^{132}$ The significance of health to the empowerment of populations and their socio-economic development is well reflected in the following observation of Gostin:

.... health is also essential for the functioning of populations. Without minimum levels of health, people cannot fully engage in social interactions, participate in the political process, exercise rights of citizenship, generate wealth, create art, and provide for the common security. A safe and healthy population builds strong roots for a country's governmental structures, social organizations, cultural endowment, economic prosperity, and national defense. Population health becomes a transcendent value because a certain level of human functioning is a prerequisite for activities that are critical to the public's welfare-social, political, and economic. ${ }^{133}$

Health is very crucial to human development and for there to be economic growth, there has to be a strong and healthy population. Empirical studies have found that the impact of health on GDP is substantial as an extra year of life expectancy is estimated to raise a country's per capital GDP by about $4 \% .{ }^{134}$

The issue here is whether stronger or weaker IP protection better enhances the development of developing countries. This cannot be theoretically ascertained but requires empirical analysis. ${ }^{135}$ Some empirical research suggests that

129 See Gutowski, above n 59, 746.

130 Z. Lazzarini, Access to HIV Drugs: Are we Changing the Two World Paradigm? 17 Connecticut Journal of International Law (2002), 281, 289.

131 Ibid.

132 Ibid.

133 L. O. Gostin, Meeting Basic Survival Needs of the World's Least Healthy People: Towards a Framework on Global Health, 96 George Town Law Journal (2008), 331, 344.

134 D. E. Bloom, D. Canning and D. T. Jamison, "Health, Wealth and Welfare”, in J. Clift (ed.), Health and Development: A Compilation of Articles From Finance and Development (IMF, 2004), pp. 10, 15. 135 See C. Fink and K. E. Maskus (eds.), Intellectual Property and Development: Lessons from Recent Economic Research (New York and Washington, DC: Oxford University Press and World Bank, 2005): at pp. 2-3. 
stronger IP protection is positively connected to some aspects of development, such as foreign technology licensing, foreign investment, and higher degree of trade. However, significant variability amongst countries and sectors prompts the conclusion that the effects of stronger IP protection will be largely informed by the underlying conditions in each country. ${ }^{136}$

The access to medicines debate has focused chiefly on the use of compulsory licensing and parallel importation in addressing the problem without the same level of focus on capacity building in developing countries. ${ }^{137}$ There is a real need to fashion IPRs in a way that will serve development interests. The pursuit of development is accordingly germane in establishing a strategic and sustainable framework for access to medicines. IPRs must promote capacity building and technology transfer, especially in relation to pharmaceutical manufacturing capacity in order to provide a durable solution to the access to medicines problem.

Some studies report that the distributive effects of pharmaceutical patents are of significant economic benefits to industrialised states whilst the potential of benefits to developing nations remains uncertain. ${ }^{138}$ Patent protection must therefore be put in the context of national strategic and fundamental goals such as the protection of public health and national industrial development. ${ }^{139}$ The access to medicines concern is not only a public health conundrum, it also raises serious issues in relation to a country's ability to foster job creations and achieve sustainable development. ${ }^{140}$ Sadly, even laws formulated as concessions to developing countries, such as the technical cooperation provision of TRIPS, may not work to the advantage of these countries. ${ }^{141}$ Peter Drahos put the situation quite aptly when he notes that "underneath the development ideology of intellectual property there lies an agenda of underdevelopment. It is all about protecting the knowledge and skills of the leaders of the pack. "142

136 Ibid., 2.

137 G. E. Evans, Strategic Patent Licensing for Public Research Organizations: Deploying Restriction and Reservation Clauses to Promote Medical R\&D in Developing Countries, 34 American Journal of Law and Medicine (2008), 175, 178.

138 K. E. Maskus and J. H. Reichman, "The Globalization of Private Knowledge Goods and the Privatization of Global Public Goods”, in K. E. Maskus and J. H. Reichman (eds.), International Public Goods and Transfer of Technology Under a Globalized Intellectual Property Regime (Cambridge: Cambridge University Press, 2005), pp. 65, 65-66.

139 R V. V. Puymbroeck, Coming to Grips with TRIPS: Conversion + Calculation, 38 Journal of Law, Medicines and Ethics (2010), 520, 527.

140 Ibid., 542.

141 See K. M. Koepsel, "How Do Developed Countries Meet Their Obligations Under Article 67 of the TRIPS Agreement?”, 44 IDEA (2004), 167.

142 See P. Drahos with J. Braithwaite, Information Feudalism: Who Owns the Knowledge Economy? 12 (UK: Earthscan Publications Limited, 2002). 
Much has been written on the flexibilities embedded in the TRIPS Agreement to enhance public interest and foster access to medicines for all. ${ }^{143}$ The essence of this paper is not to reproduce the overwhelming volume of literature in this area. It is however very important to emphasise the need for developing countries to take full advantage of the existing flexibilities in the TRIPS Agreement to promote their socio-economic interest. For instance, Article 27 of the TRIPS Agreement which requires countries to recognise patents for all inventions that are new and that possess an inventive step does not contain a definition of "new". With respect to pharmaceutical patents, developing countries may adopt a definition of new that does not allow the "evergreening" of such patents. It is also important to note that there currently exists a plethora of bilateral and plurilateral free trade agreements within the WTO system that tend to substantially erode the flexibilities in the TRIPS Agreement through the higher IP standards they impose on signatory countries. ${ }^{144}$ The importance of not whittling down the existing flexibilities through free trade agreements cannot be overemphasised.

In sum, it is submitted that whilst the flexibilities in TRIPS might be effective in addressing public health emergencies in developing countries, a durable solution lies in having a framework within the IP system that will facilitate capacity building, technology transfer and human development. The framework for the protection of intellectual property law in any country should not be constructed in a way that will make it a real impediment to human development and the advancement of the socio-economic rights of the world populations as that will run afoul of the underlying objective of the international legal order. The promotion of the socio-economic advancement of nations and their citizens

143 See M. Nkoma, Rwanda's new intellectual property law and the compulsory licensing for export under the WTO: not quite a panacea, 21 African Journal of International and Comparative Law, no. 2 (2013), 279; D. Nicol and O. Owoeye, Using TRIPS Flexibilities to Facilitate Access to Medicines, 91 Bulletin of the World Health Organisation, no. 7 (2013), 533-539; H. G. Ruse-Khan, The International Law Relation Between TRIPS And Subsequent TRIPS-Plus Free Trade Agreements: Towards Safeguarding TRIPS Flexibilities? 18 Journal of Intellectual Property Law (2011), 325; M. Buckley, Looking Inward: Regional Parallel Trade as a means of Bringing Affordable Drugs to Africa, 41 Seton Hall Law Review (2011), 625; H. Hestermeyer, Human Rights and the WTO: The Case of Patents and Access to Medicines (Oxford: Oxford University Press, 2007).

144 See generally, R. Lopert and D. Gleeson, The High Price of "Free” Trade: U.S. Trade Agreements And Access To Medicines, 41 Journal of Law, Medicine \& Ethics (2013), 199; Ping Xiong, Patents in TRIPS-Plus Provisions and the Approaches to Interpretation of Free Trade Agreements and TRIPS: Do They Affect Public Health? 46 Journal of World Trade (2012), 155; S. K. Sell, TRIPS was Never Enough: Vertical Forum Shifting, FTAs, ACTA, TPP, 18 Journal of Intellectual Property Law (2011), 447; J. Kelsey, Free Trade Agreements - Boon or Bane?: Through the Lens of PACER, 37 Victoria University of Wellington Law Review (2006), 391. 
is one of the fundamental objectives of international law and international relations and this is well articulated in Article 1(3) of the United Nations Charter which clearly provides that the purposes of the United Nations include:

To achieve international co-operation in solving international problems of an economic, social, cultural, or humanitarian character, and in promoting and encouraging respect for human rights and for fundamental freedoms for all without distinction as to race, sex, language, or religion....

The development objective of the IP system should therefore assume something much stronger than its current inchoate form and IP protection should not render otiose measures taken in good faith to enhance human development in poor countries. Measures genuinely taken to foster the development objectives and socio-economic interests of WTO members should not be considered inconsistent with the TRIPS Agreement as such measures are fully countenanced by Articles 7 and 8 of the Agreement. International peace, economic growth and the general pursuit of development are the overarching objectives of the international legal order and patent law can be designed at national levels to facilitate the actualisation of those objectives.

\section{Conclusion}

The interface between IP and development will continue to remain controversial because of the vagaries of intricate economic issues involved. Whilst it may be conceded that the right to development in international law has not attained a status that can be considered to carry a significant legal weight, the concept of development seems to be an essential and fundamental part of the current international legal order such that it can be argued that it is something close to a peremptory norm of international law. To this extent, developing countries may resist efforts to erode the current flexibilities in the TRIPS Agreement by relying on the international law of development or the concept of development in international law. It is certainly impossible to reconcile a "one size fits all" or a highly harmonised IP regime with the varying needs of developing countries and this is why even the significant harmonisation achieved in the TRIPS Agreement still leaves room for some flexibilities.

The effective utilisation of these flexibilities is however increasingly being undermined by the myriad free trade agreements being pursued especially by the US worldwide. There is a compelling need for trade and IP agreements to foster rather than impede the developmental objectives of the world's nations. Whilst the existing TRIPS flexibilities may address public health emergencies in 
developing countries, the effectual recognition of development in the global IP system can provide a more durable solution to the access to medicines crisis in developing countries. It is submitted that developing countries can vigorously rely on the concept of development as a fundamental principle of international law in their resistance of provisions in trade agreements that tend to impede rather than foster development.

More importantly, developing countries must have an IP implementation plan that sufficiently takes cognisance of their peculiar developmental needs. It is already established in WTO jurisprudence that the question of what amounts to developmental needs is peculiarly one for the country concerned to determine. Developing countries can thus fashion their IP implementation plan in a manner supportive of the national interest and socio-economic development without running afoul of their international obligations as such measures will be fully countenanced by the combination of Articles 7 and 8 of the TRIPS Agreement. With respect to patents, countries in developing world should use all available flexibilities in the TRIPS Agreement, which are further reinforced by the WTO Ministers in the Declaration on TRIPS and Public Health, to implement national patent laws in a way that protects public health and the advancement of the well-being of their citizenry.

Acknowledgments: The author acknowledges with thanks the research grants from the University of Tasmania Law School and the Institute of for the Study of Social Change, University of Tasmania. Special thanks also to Prof Dianne Nicol and Dr Jane Nielsen, University of Tasmania, Prof Margaret Chon, Seattle University and the anonymous peer reviewers for their comments on the manuscript of the article. 